\title{
Smoldering multiple myeloma: prevalence and current evidence guiding treatment decisions
}

This article was published in the following Dove Press journal: Blood and Lymphatic Cancer:Targets and Therapy

\section{Agnieszka Blum \\ Despina Bazou \\ Peter O'Gorman}

Department of Hematology, Mater Misericordiae University Hospital, Dublin, UK
Correspondence: Agnieszka Blum Department of Hematology, Mater Misericordiae University Hospital, Eccles St, Inns Quay, Dublin 7, Dublin, UK

Tel +353 I 8034 I 74

Fax +353 I 8500962

Email agnieszkablum@mater.ie

\begin{abstract}
Smoldering multiple myeloma (SMM) is an asymptomatic plasma cell proliferative disorder associated with risk of progression to symptomatic multiple myeloma (MM) or amyloidosis. In comparison to monoclonal gammopathy of undetermined significance (MGUS), SMM has a much higher risk of progression to MM. Thanks to advances in our understanding of the risk factors, the subset of patients with ultra-high risk of progression to $\mathrm{MM}(80 \%-90 \%$ at 2 years $)$ has been identified. The revision of the diagnostic criteria resulted in changes in the management of this cohort of patients. In contrast to the management guidelines for MGUS patients, SMM patients need to be studied more intensively in order to identify biomarkers necessary for accurate risk stratification. In this review, we focus on the risk of progression from SMM to MM, as well as the influence of early treatment on overall survival, time to progression and quality of life.

Keywords: smoldering multiple myeloma, risk factor, biomarker, genomic aberrations, glycan analysis
\end{abstract}

\section{Introduction}

Smoldering multiple myeloma (SMM) was first defined by Kyle and Greipp in $1980 .{ }^{1}$ They described a series of 6 patients who fulfilled the diagnostic criteria for multiple myeloma (MM) but had a different clinical outcome. Since then, the understanding of prevalence, diagnosis, risk of progression, and possible treatment has greatly increased. The occurrence of MM is preceded by an indolent expansion of clonal plasma cells (CPCs), known as monoclonal gammopathy of undetermined significance (MGUS) that progresses to SMM prior to malignancy. This disease continuum between MGUS, SMM, and MM provides a unique platform for investigating the genomic hierarchy, as well as the clonal heterogeneity and clonal evolution of these disease stages. Furthermore, proteomics analysis has provided valuable insight into the role of the tumor microenvironment in the regulation of cell survival, proliferation, differentiation, and metastasis. Genomic and proteomic analyses can potentially help us distinguish between a benign MM state, such as MGUS, from an asymptomatic malignancy such as SMM.

\section{Diagnosis}

In 2014, the International Myeloma Working Group (IMWG) updated the diagnostic criteria for MGUS, SMM and MM. ${ }^{2}$ The distinction between the different disease stages is based on biological parameters and focuses on the presence of clinical symptoms (Table 1). MGUS is defined by a serum M-protein level of $<3 \mathrm{~g} / \mathrm{dL}$, a bone marrow plasma cell (BMPC) infiltration of $<10 \%$, and the absence of clinical complications. 
SMM is defined by serum M-protein (IgG or IgA) levels of $\geq 3 \mathrm{~g} / \mathrm{dL}$ and/or clonal BMPCs of $10 \%-60 \%$ in the absence of myeloma defining events (MDEs) or amyloidosis. The updated IMWG diagnostic criteria for MM (Table 2) include presence of $\mathrm{M}$ protein in blood or urine, a BMPC infiltration of $>10 \%$, or biopsy-proven bony or extramedullary plasmacytoma as well as MDEs. MDE would include CRAB (calcium [elevated], renal failure, anemia, bone lesions) signs such as hypercalcemia, radiological bone lesions, anemia, and renal failure or any one or more of the following biomarkers of malignancy: a clonal BMPC percentage of $>60 \%$, involved/ uninvolved serum free light chain (SFLC) ratio of $>100$ or $>1$, and focal lesions (FLs) detected by magnetic resonance imaging (MRI) studies.

\section{Prevalence}

The lack of population-based disease registries as well as changes in the diagnostic criteria over the last decade have made epidemiological data on the prevalence of plasma cell (PC) disorders (including SMM) difficult to acquire. However, the
American National Cancer Data Base (NCDB) study provided some insight into the incidence of SMM, estimating it at 0.9 cases per 100,000 persons,${ }^{3}$ similar to that reported by a European study, where 0.4 cases per 100,000 persons were stated. ${ }^{4}$ The median patient age at diagnosis in the NCDB was 67 years.

\section{Pathogenesis and natural course of disease}

The pathology of disease progression from benign MGUS to malignancy is characterized by a sequence of genetic aberrations. Such genetic aberrations begin with germline mutations that predispose to the disease are followed by early and likely malignancy-initiation mutations, while further acquisition of genomic aberrations ultimately leads to disease progression and resistance to treatment.

Primary events are usually divided into hyperdiploidlike trisomy of chromosomes 3, 5, 7, 9, 11, 15, 19, $21^{6}$ and nonhyperploid-like translocations in the genes encoding Ig heavy chains $(\operatorname{IgH}){ }^{7}$ The presence of specific chromosome abnormalities such as $\operatorname{del}(17 \mathrm{p}), \mathrm{t}(4: 14), 1 \mathrm{q}$ gains,${ }^{8}$ and

Table I Revised International Myeloma Working Group diagnostic criteria for MGUS, SMM and MM

\begin{tabular}{|c|c|c|c|}
\hline \multirow[t]{2}{*}{ Criteria } & \multicolumn{3}{|c|}{ Disease stage } \\
\hline & MGUS & SMM & $\mathbf{M M}$ \\
\hline $\begin{array}{l}\text { Serum } \\
\text { M-protein }\end{array}$ & $<3 \mathrm{~g} / \mathrm{dL}$ & $\begin{array}{l}\text { Serum monoclonal protein } \\
\text { - IgG or } \lg A \geq 3 \mathrm{~g} / \mathrm{dL} \text { or } \\
\text { Bence-Jones protein } \\
\geq 500 \mathrm{mg} / 24 \text { hours }\end{array}$ & \\
\hline $\begin{array}{l}\text { Bone marrow } \\
\text { infiltration }\end{array}$ & $<10 \%$ & Clonal BMPCs 10\%-60\% & $\begin{array}{l}>10 \% \text { or biopsy-proven plasmacytoma when CRAB symptoms present or } \\
\text { clonal BMPC percentage } \geq 60 \%\end{array}$ \\
\hline $\begin{array}{l}\text { Presence of } \\
\text { myeloma defining } \\
\text { events or } \\
\text { amyloidosis }\end{array}$ & None & None & $\begin{array}{l}\text { CRAB symptoms: } \\
\text { I. hypercalcemia: serum calcium }>0.25 \mathrm{mmol} / \mathrm{L}(>\mathrm{I} \mathrm{mg} / \mathrm{dL}) \text { higher than } \\
\text { the upper limit of normal or }>2.75 \mathrm{mmol} / \mathrm{L}(>\mathrm{II} \mathrm{mg} / \mathrm{dL}) \\
\text { 2. renal insufficiency: serum creatinine }>177 \mathrm{mmol} / \mathrm{L}(2 \mathrm{mg} / \mathrm{dL}) \text { or } \\
\text { creatinine clearance }<40 \mathrm{~mL} / \mathrm{min} \text {; } \\
\text { 3. anemia: hemoglobin value of }>2 \mathrm{~g} / \mathrm{dL} \text { below the lower normal limit or } \\
\text { a hemoglobin value }<10 \mathrm{~g} / \mathrm{dL} \text {; } \\
\text { 4. bone lesions: one or more osteolytic lesions revealed by skeletal } \\
\text { survey, CT or PET-CT. }\end{array}$ \\
\hline
\end{tabular}

Note: Data from Rajkumar et al. ${ }^{2}$

Abbreviations: BMPC, bone marrow plasma cell; CRAB, calcium (elevated), renal failure, anemia, bone lesions; CT, computed tomography; MGUS, monoclonal gammopathy of undetermined significance; MM, multiple myeloma; PET-CT, positron emission tomography-computed tomography; SMM, smoldering multiple myeloma.

Table 2 Clinical evaluation of newly diagnosed SMM

\begin{tabular}{ll}
\hline Initial evaluation & History of present illness and past medical history \\
& Physical examination \\
FBC, bone marrow aspirate and & Percentage of bone marrow infiltration by clonal plasma cells, flow cytometry, conventional \\
biopsy & cytogenetics, and fluorescence in situ hybridization analysis \\
Biochemical studies & Creatinine, calcium; B2-microglobulin, LDH, albumin \\
Protein studies & Total serum protein, serum protein electrophoresis, 24-h urine sample protein electrophoresis, serum \\
& and urine immunofixation, SFLCs, SFLCR \\
Radiological studies & Skeletal survey (CT) or PET-CT; MRI of thoracic and lumbar spine and pelvis or WB-MRI
\end{tabular}

Note: Data from Rajkumar et al. ${ }^{2,5}$

Abbreviations: FBC, full blood count; LDH, lactate dehydrogenase; MRI, magnetic resonance imaging; PET-CT, positron emission tomography-computed tomography; SFLC, serum free light chain; SFLCR, serum free light chain ratio; SMM, smoldering multiple myeloma; WB-MRI, whole-body magnetic resonance imaging. 
hyperdiploidy, such as $\mathrm{t}(4 ; 14), \mathrm{t}(6 ; 14), \mathrm{t}(11 ; 14), \mathrm{t}(14 ; 16)$ and $\mathrm{t}(14 ; 20),{ }^{9}$ have been found to correlate with increased risk of disease progression from MGUS to SMM. Large, wholeexome sequencing and gene expression profiling studies have provided new insights into the clonal heterogeneity and evolution of the disease. In particular, a 70-gene expression profiling (GEP-70) signature ${ }^{10}$ as well as a 4-gene signature $(\mathrm{GEP}-4)^{11}$ are strong predictors of risk of progression from SMM to MM. Moreover, these gene expression signatures suggest that dysregulation of mitotic checkpoints contribute to the disease's genomic instability. ${ }^{12}$ The top four genes in descending order of predictive power were RRM2 (2p25$\mathrm{p} 24)$, beta subunit of ribonucleotide reductase $(R N R), D T L$ (1q32) also called retinoic acid-regulated nuclear matrixassociated protein - RAMP, TMEM48 (1p32.3) and ASPM (1q31). RRM2 overexpression is associated with cellular invasiveness, metastasis and tumor angiogenesis by activation of the ERK1/2 signaling pathway in cancer. DTL has been implicated in oncogenesis of solid tumors via its role in apoptosis and cell cycle control. ASPM was shown previously to be a marker of poor prognosis in MM. The progression to clinical MM can also be linked to secondary driver events like activation of c-myc, ${ }^{13,14}$ or other somatic mutations affecting MAPK, NFאB and DNA-repair pathways. ${ }^{15,16}$

Sequential whole-genome sequencing studies of SMM patients who progressed to MM demonstrated little difference in the median number of nonsynonymous single nucleotide variations (SNVs) present at both stages. ${ }^{17}$ In these studies, progression to clinical MM in most patients did not involve new/recurrent somatic mutations, although there was some subclonal selection with progression. Moreover, differences in site-specific synonymous SNVs and copy number variations were observed to contribute to disease progression. $^{18}$

Protein analysis, specifically looking at serum proteins found to have differences in abundance levels associated with disease phenotype, in this case SMM and MM patients, can provide clinicians with a suite of biomarkers that will aid the management of those patients who are of high risk into progressing to MM. While extensive work has been conducted on the use of proteomic methods to find potential biomarkers in MM patients, little evidence exists in the literature of the use of proteomics for the delineation of the different $\mathrm{MM}$ disease states. Mittermayr et al ${ }^{19}$ recently profiled the glycomes of polyclonal IgG in different disease subgroups across the spectrum of PC disorders (MGUS, SMM, newly diagnosed MM, remission, relapse) and compared them to healthy controls. These authors showed a low total abundance of agalactosylated neutral glycans in the newly diagnosed and SMM, which suggested a potential association with inflammatory changes. Furthermore, they showed that the relapse myeloma group had the lowest abundance of total terminal galactose, while that of smoldering myeloma was highest. Such glycotraits could act as markers of disease progression.

The challenge of current genetic testing is to identify a subset of SMM patients that are of high risk into progressing to MM. With increased knowledge of the molecular pathways and genetic mutations occurring during SMM to MM progression, genetic testing has the potential to identify these high-risk patients and ultimately direct a tailored, patient-specific management strategy.

\section{Risk assessment}

Most of the patients diagnosed with SMM will eventually progress to symptomatic $\mathrm{MM}$ and will require treatment. The time-to-progression (TTP) to MM varies significantly among patients as SMM is a heterogeneous disorder (Tables 3 and 4). The overall risk of progression was found to be higher in the early years after diagnosis: $10 \%$ per year for the first 5 years, $3 \%$ per year during the following 5 years, and only $1 \%$ per year after 10 years. However, the cumulative probability of progression to active MM or amyloidosis (AL) was $51 \%$ at 5 years, $66 \%$ at 10 years, and $73 \%$ at 15 years. ${ }^{20}$ Similar results were found in a prospective study published by Neben et al, ${ }^{9}$ where a median time of progression at 5.6 years was reported with a cumulative progression rate of $46 \%$ over 5 years.

\section{Tumor burden assessment Bone marrow infiltration}

Tumor burden can be assessed by the percentage of bone marrow infiltration by PCs or size of serum M-protein and presents a significant risk factor of progression. Kyle et $\mathrm{al}^{21}$ showed that the percentage of bone marrow involvement correlates with the median TTP. ${ }^{21}$ Further studies demonstrated that the risk of progression rises dramatically when the BMPCs level is $\geq 60 \%$ and the estimated risk of disease progression at 2 years is $90 \% .^{22-24}$ This high-risk factor has been incorporated into the new IMWG MM diagnosis guidelines. $^{2}$

\section{SFLC ratio}

SFLC ratio was evaluated as a marker for progression in SMM. Larsen et $\mathrm{al}^{25}$ found that a serum involved/ 
Table 3 SMM risk factors associated with progression to clinical MM"

\begin{tabular}{|c|c|c|}
\hline Risk factor & Assessment criteria & References \\
\hline \multirow[t]{6}{*}{ Tumor burden } & $>10 \%$ clonal plasma cell bone marrow infiltration & 2,20 \\
\hline & $\geq 3 \mathrm{~g} / \mathrm{dL}$ of serum M-protein & 2 \\
\hline & Serum free light chain ratio between 0.125 and 8 & 26 \\
\hline & Bence Jones proteinuria positive from 24-h urine sample & 31 \\
\hline & Peripheral blood circulating PCs $>5 \times 10^{6} / \mathrm{L}$ & 35 \\
\hline & Peripheral blood circulating PCs $\geq 150$ by flow cytometry & 36 \\
\hline Serum free light chain ratio & $\geq 100$ & 25 \\
\hline \multirow[t]{2}{*}{$\begin{array}{l}\text { Immunoparesis and } \\
\text { immunophenotyping }\end{array}$} & $\begin{array}{l}\text { Immunoparesis }(>25 \% \text { decrease in one or both uninvolved immunoglobulins } \\
\text { relative to the lowest normal value }\end{array}$ & 32,27 \\
\hline & $\begin{array}{l}>95 \% \text { of aberrant PCs by flow cytometry within the PC bone marrow } \\
\text { compartment }\end{array}$ & 43 \\
\hline \multirow[t]{5}{*}{ Genetic abnormalities } & $\mathrm{t}(4 ; 14)$ & 7,9 \\
\hline & dell7p & \\
\hline & $+\mathrm{lq} 24$ & \\
\hline & Hyperploidy & \\
\hline & Gene expression profiling risk score $>-0.26$ & 10 \\
\hline \multirow[t]{2}{*}{ Radiological assessment } & $\begin{array}{l}\text { Newly detected FLs or increase in diameter of existing FL and a novel or } \\
\text { progressive diffuse infiltration on WB-MRI }\end{array}$ & $37,38,39$ \\
\hline & Positive PET-CT with no underlying osteolytic lesion & 44 \\
\hline
\end{tabular}

Table 4 Clinical trials investigating the SMM risk factors for progression to clinical MM

\begin{tabular}{|c|c|c|c|c|}
\hline Risk factor & $\begin{array}{l}\text { Patients } \\
\text { n }\end{array}$ & $\begin{array}{l}\text { Patients with } \\
\text { the risk factor } \\
\text { n (\%) }\end{array}$ & TTP & References \\
\hline \multirow[t]{3}{*}{ BMPCs $\geq 60 \%$} & 655 & $21(3.2)$ & 2 -year: $95 \%$ & 22 \\
\hline & 96 & $8(89)$ & Median 15 months & 23 \\
\hline & 135 & $6(4.4)$ & 2-year: $100 \%$ & 24 \\
\hline \multirow[t]{3}{*}{ SFLC ratio $>100$} & 586 & $90(15)$ & 2-year: 79\% & 25 \\
\hline & 96 & $7(7)$ & Median 13 months & 23 \\
\hline & 321 & $23(7)$ & 2 -year: $30 \%$ & 27 \\
\hline Evolving pattern of serum paraprotein & 53 & $22(4 I)$ & Median I.3 years & 28 \\
\hline Immunophenotype & 93 & $14(15)$ & Median 51 months & 32 \\
\hline \multirow[t]{3}{*}{ Circulating clonal plasma cells } & 91 & $14(15)$ & 2-year: 71\% & 35 \\
\hline & 100 & $9(9)$ & 2-year: $78 \%$ & 36 \\
\hline & & & Median 9 months & \\
\hline \multicolumn{5}{|l|}{ Genetic abnormalities } \\
\hline$t(4 ; 14)$ & 351 & $36(10)$ & Median 28 months & 7 \\
\hline $\operatorname{del}(17 p)$ & 351 & $6(2)$ & Median 24 months & 7 \\
\hline$t(4 ; \mid 4)$ & 248 & $22(9)$ & Median 5.7 years & 9 \\
\hline $\operatorname{del}(17 p)$ & 248 & $15(6)$ & Median 5.6 years & 9 \\
\hline$+|q 2|$ & 248 & $73(30)$ & Median 3.8 years & 9 \\
\hline GEP-70 & 126 & $31(29)$ & 2-year: $49.7 \%$ & 10 \\
\hline GEP-4 & 104 & $14(13)$ & 2 -year: $81.8 \%$ & 11 \\
\hline \multirow[t]{2}{*}{$>I$ focal lesion on MRI } & 149 & $23(15)$ & Median I 3 months & 37 \\
\hline & 67 & $9(13)$ & 2 -year: $69 \%$ & 39 \\
\hline $\begin{array}{l}\text { Positive PET-CT with no underlying } \\
\text { osteolytic lesion }\end{array}$ & 120 & $19(16 \%)$ & 2 -year: $48 \%$ & $4 I$ \\
\hline
\end{tabular}

Abbreviations: BMPC, bone marrow plasma cell; MRI, magnetic resonance imaging; MM, multiple myeloma; PET-CT, positron emission tomography-computed tomography; SFLC, serum free light chain; SMM, smoldering multiple myeloma; TTP, time-to-progression. 
uninvolved FLC ratio of at least 100 is associated with a risk of progression to symptomatic disease of $72 \%$ at 2 years. ${ }^{25} \mathrm{~A}$ ratio of involved to uninvolved SFLC of $\geq 100$ has been recently added to MDE and was included by the IMWG in recent guidelines. ${ }^{2}$ In addition, a kappa/ lambda SFLC ratio of $<0.125$ and $>8$ was found to be associated with an increase in the risk of progression to MM. ${ }^{26}$ However, the Danish Myeloma Group ${ }^{27}$ found no significant threshold for the SFLC ratio in their analysis of an SMM patient cohort.

\section{Evolving pattern of serum paraprotein}

The evolution of disease parameters, such as serum paraprotein or urine paraprotein, following the initial diagnosis is important in estimating the risk of progression. This concept was introduced more than a decade $\operatorname{ago}^{28}$ and enables distinction between evolving and stable SMM. ${ }^{29}$ The evolving type can be defined by: 1) if the concentration of M-protein is $>3 \mathrm{~g} / \mathrm{dL}$ at baseline and an increase in M-protein of at least $10 \%$ within the first 6 months; or 2 ) if the concentration of M-protein is $<3 \mathrm{~g} / \mathrm{dL}$ at baseline and a progressive increase in M-protein in each consecutive annual measurement over a 3 -year period diagnosis is reported. ${ }^{30}$

\section{Bence Jones proteinuria}

The presence of Bence Jones proteinuria at diagnosis of SMM is associated with a risk of progression to malignancy. A study ${ }^{31}$ of 147 SMM patients showed that individuals with M-protein and Bence Jones proteinuria have a significantly higher risk of progression to active disease ( $22 \mathrm{vs.} 83$ months, $P<0.001)$. Furthermore, when the Bence Jones proteinuria exceeded $500 \mathrm{mg}$ in 24-h urine samples, the risk was even higher, with a median TTP of 7 months. ${ }^{31}$

\section{Immunophenotype}

New generation multiparameter flow cytometry (MFC) has been used to determine SMM prognosis, by distinguishing and quantitating aberrant and normal PCs infiltrating the bone marrow. Pérez-Persona et $\mathrm{al}^{32}$ showed that $60 \%$ of the SMM patients included in their study had an aberrant immunophenotype. The risk of progression to malignancy was significantly higher than those with lower percentage of malignant PCs. ${ }^{32}$

\section{Circulating plasma cells (CPCs)}

CPCs were detected at newly diagnosed MM and SMM. ${ }^{33}$ Since there was only a weak correlation between tumor mass and CPCs, it was suggested that the appearance of CPCs may be a reflection of tumor biology. ${ }^{34}$ The presence of $>5 \times 10^{6} / \mathrm{L}$ CPCs, estimated by slide-based immunofluorescence, is a risk factor associated with a shorter TTP. ${ }^{35}$ In addition, the occurrence of at least 150 CPCs in 150,000 cellular events measured by means of 6-color flow cytometry was also shown to be associated with shorter TTP within $2-3$ years in $78 \%$ of the analyzed patients. ${ }^{36}$

\section{Immunoparesis}

Immunoparesis is defined as the reduction in the levels of uninvolved immunoglobulins and presents an independent risk factor. Its prevalence correlates with tumor burden. ${ }^{20,32}$ However, its value as a risk factor for progression remains controversial and varies between the studies. ${ }^{9,23}$ Sørrig et $\mathrm{al}^{27}$ recently reported that immunoparesis and $\mathrm{M}$-protein levels of $>30 \mathrm{~g} / \mathrm{L}$ can significantly affect TTP to MM. ${ }^{27}$

\section{Genetic changes}

Certain cytogenetic abnormalities have major prognostic significance in symptomatic MM. One of the studies performed by the Mayo Clinic team ${ }^{7}$ evaluated the prognostic value of cytogenetics in a cohort of 351 SMM patients. The TTP of patients with a $17 \mathrm{p}$ deletion was 24 months. Patients with a $\mathrm{t}(4 ; 14)$ translocation had a median TTP of 28 months. Patients with trisomies progressed to malignancy after 34 months, while patients with other anomalies like $\mathrm{t}(11 ; 14)$, MAF translocations, other IgH translocations, monosomy 13/del(13q) after 55 months. Furthermore, the presence of cytogenetic abnormalities determined the overall survival (OS). After diagnosis of SMM, OS for patients with $\mathrm{t}(4 ; 14)$ translocations was 105 months and 147 months for patients with $\mathrm{t}(11 ; 14)$ aberrations. Based on these results, the authors described four SMM patient groups based on their risk of progression: 1) high-risk patients, harboring $\mathrm{t}(4 ; 14)$ and/or $\operatorname{del}(17 \mathrm{p}) ; 2)$ intermediaterisk patients carrying trisomies; 3) standard-risk patients with $\mathrm{t}(11 ; 14), \mathrm{t}(14 ; 16)$, or $\mathrm{t}(14 ; 20)$, and trisomies/IgH translocation combination; and 4) low-risk patients where no cytogenetic abnormalities are detected. ${ }^{7}$

The Heidelberg group also demonstrated the significance of $\mathrm{t}(4 ; 14)$, gain of 1q21 chromosome and hyperdiploidy as independent risk factors for progression to malignancy of SMM patients. ${ }^{9}$ A different approach was explored by the SWOG S0120 study. ${ }^{10}$ These authors analyzed the gene expression profiles of 105 SMM patients. The presence of a 70-gene expression profiling signature (which partly correlates with chromosome 1 abnormalities and identifies 
high-risk SMM patients was found to be a strong predictor of risk of progression, ${ }^{10}$ this was also true for a 4-gene signature. ${ }^{11}$ Furthermore, the combination of elevated SFLC, M-spike, and GEP70 in a subset of high-risk patients leads to an even higher progression risk (67\% at 2 years). More importantly, the absence of these factors in SMM patients predicted low progression risk.

\section{Radiological assessment}

The modern imaging techniques like MRI and positron emission tomography-computed tomography (PET-CT) are part of the workup of patients assessed for MM and SMM; furthermore, they can also predict progression risk in SMM. Hillengass et $\mathrm{al}^{37}$ have demonstrated that $28 \%$ of patients with SMM had one or more FLs on whole-body MRI (WBMRI). ${ }^{36}$ The presence of more than 1 FL (15\% of the study population) was associated with a higher risk of progression to symptomatic disease, with an estimated 2-year progression of $65 \%-70 \%$. Various research groups have independently shown that the presence of new FLs or an increase in diameter of the existing FLs, as well as novel or progressive diffuse infiltration seen by means of MRI, are associated with high risk of progression to $\mathrm{MM} \cdot{ }^{37-39}$

PET-CT is considered a valuable tool for patients requiring $\mathrm{PC}$ disorder workup. Furthermore, is may be an alternative imaging modality for SMM assessment if WBMRI is not available. ${ }^{40}$ Zamagni et $\mathrm{al}^{41}$ reported that positive PET-CT results with no underlying osteolytic lesions have been reported in $10 \%$ of patients. Positive PET-CT results were also associated with high risk of progression to symptomatic disease $(48 \%$ at 2 years compared with $32 \%$ for PET-CT-negative; $P<0.007) .{ }^{41}$ Similar percentage of progression ( $56 \%$ at 2 years for PET-CT positive and $28 \%$ for PET-CT negative; $P<0.001)$ was also identified by the Mayo Clinic Group ${ }^{42}$ within a subgroup of 132 SMM patients. The rate of progression was even higher among patients where PET-CT was performed within 3 months of their diagnosis of SMM (74\% in PET-CT positive vs. $27 \%$ in PET-CT negative).

\section{Prediction of progression to MM}

The most important step following the diagnosis of SMM is an insightful analysis of the risk of disease progression. Several models have been proposed, but unfortunately the components incorporated in these analyses are not consistent, thus making the assessment of the risk of progression to malignancy difficult (Table 5).
The most familiar prospectively validated models are the Mayo Clinic and the Spanish Myeloma Group models. ${ }^{20,26,32}$ The Mayo Clinic model uses 3 risk factors including: 1) a monoclonal protein of $>3 \mathrm{~g} / \mathrm{dL} ; 2)$ an abnormal SFLC ratio ( $<8$ or $>0.125$ ); and 3 ) the extent of BMPC involvement $(>10 \%)$. Each of these factors independently correlated with an increased risk of progression. The probability of progression at 5 years was $25 \%, 51 \%$, and $76 \%$, depending on whether the patients had 1,2 , or 3 risk factors, with a median TTP of 10, 5.1 and 1.9 years, respectively.

The Spanish Myeloma Group model is based on two risk factors: 1) predominance of clonal cells in the BMPC compartment using MFC; and 2) the presence of immunoparesis (defined as a decrease by $>25 \%$ of the level of 1 of the 2 other uninvolved immunoglobulins). Depending on whether patients had none, one, or both risk factors, progression rates at 5 years were $4 \%, 46 \%$, and $72 \%$, respectively. ${ }^{32}$

Both studies suggested that the progression probability of patients with low-risk profile was $1 \%$ per year. Furthermore, both models were analyzed using a one-on-one comparison of 77 selected SMM patients. This study revealed a rather low concordance rate of $29 \%$ in overall patient risk classification. ${ }^{45}$ However, it was suggested to use both models complementarily rather than alternatively, as well as adding new biomarkers to assess the risk of progression more accurately.

Other upcoming risk models incorporate novel clinical and biological disease attributes, such as the gene expression score or SFLC ratio. Two of the recent studies: the SWOG S0120 and the University of Pennsylvania models used criteria that also included genetic factors and thus defined a highrisk group that had more than $80 \%$ progression at 2 years. ${ }^{11,46}$ Greater understanding of the disease development as well as more accurate identification of high-risk SMM patients will be crucial for success of future interventions.

\section{Treatment approaches (literature review)}

Early intervention studies evaluated the benefit of early versus delayed treatment with oral melphalan and prednisone for SMM patients. No benefit in terms of response rate, progression-free survival, or $\mathrm{OS}^{50,51}$ was shown. Similarly, trials investigating the effect of bisphosphonate showed no clear antitumoral effects; bisphosphonate was shown to have a positive effect on the bone metabolism as a significant reduction in the incidence of skeletal-related events was reported. ${ }^{52-54}$ One of the first agents showing to 
Table 5 Overview of the SMM risk stratification models

\begin{tabular}{|c|c|c|c|c|c|}
\hline Risk model & $\begin{array}{l}\text { High-risk patients, } \\
\text { no of patients/no } \\
\text { high-risk patients }\end{array}$ & Risk factors & $\begin{array}{l}\text { Definition } \\
\text { of high risk }\end{array}$ & $\begin{array}{l}\text { TTP for high- } \\
\text { risk patients }\end{array}$ & References \\
\hline Mayo Clinic & $276 / 27$ & $\begin{array}{l}\text { BMPC } \geq 10 \% \\
\text { M-protein } \geq 3 \mathrm{~g} / \mathrm{dL}\end{array}$ & All RF & 5 -year: $69 \%$ & 20 \\
\hline Mayo Clinic & $273 / 78$ & $\begin{array}{l}\text { BMPC } \geq 10 \% \\
\text { M-protein } \geq 3 \mathrm{~g} / \mathrm{dL}\end{array}$ & All RF & 5-year: 76\% & 26 \\
\hline $\begin{array}{l}\text { Spanish Myeloma } \\
\text { Group }\end{array}$ & $93 / 39$ & $\begin{array}{l}\geq 95 \% \text { aberrant PCs within BMPCs } \\
\text { Immunoparesis }\end{array}$ & All RF & 5-year: $76 \%$ & 32 \\
\hline SWOG SOI20 & $105 / 14$ & $\begin{array}{l}\text { Elevated 4-gene expression score } \\
\text { Monoclonal protein } \geq 3 \mathrm{~g} / \mathrm{dL} \\
\text { Serum albumin }<3.5 \mathrm{~g} / \mathrm{dL}\end{array}$ & $\begin{array}{l}\text { 4-gene } \\
\text { expression } \\
\text { score } \geq 9.28\end{array}$ & 2 -year: $86 \%$ & 11 \\
\hline PENN & I35/NA & $\begin{array}{l}\text { BMPC } \geq 10 \% \\
\text { SFLCR } \geq 50 \\
\text { Serum albumin } \leq 3.5 \mathrm{~g} / \mathrm{dL}\end{array}$ & 2-3 RF & 2-year: $81 \%$ & 46 \\
\hline Heidelberg & $248 / 44$ & $\begin{array}{l}\operatorname{del}(|7 \mathrm{p}| 3) ; \mathrm{t}(4 ; \mid 4) \text { or }+|\mathrm{q} 2| \\
\text { Monoclonal protein } \geq 2 \mathrm{~g} / \mathrm{dL}\end{array}$ & All RF & 3 -year: $59 \%$ & 9 \\
\hline $\begin{array}{l}\text { Czech Myleoma } \\
\text { Group }\end{array}$ & $287 / N A$ & $\begin{array}{l}\text { Immunoparesis } \\
\text { Monoclonal protein } \geq 2.3 \mathrm{~g} / \mathrm{dL} \\
\text { Involved: uninvolved } \mathrm{SFLC}>30\end{array}$ & All RF & 2-year: $79 \%$ & 47 \\
\hline $\begin{array}{l}\text { Danish Myeloma } \\
\text { Group }\end{array}$ & $321 / 42$ & $\begin{array}{l}\text { Immunoparesis } \\
\text { Monoclonal protein } \geq 3 \mathrm{~g} / \mathrm{dL}\end{array}$ & All RF & 2 -year: $38 \%$ & 27 \\
\hline Barcelona & $207 / 67$ & $\begin{array}{l}\text { Evolving pattern } \\
\text { Serum M-protein } \geq 3 \mathrm{~g} / \mathrm{dL} \\
\text { Immunoparesis }\end{array}$ & ALL RF & 2 -year: $80 \%$ & 48 \\
\hline Japanese & $301 / N A$ & $\begin{array}{l}\text { Beta } 2 \text {-microglobulin } \\
\geq 2.5 \mathrm{mg} / \mathrm{L} \\
\text { M-protein increment rate }>1 \mathrm{mg} / \mathrm{dL} / \mathrm{d}\end{array}$ & $2 \mathrm{RF}$ & 2-year: $67.5 \%$ & 49 \\
\hline $\begin{array}{l}\text { Mayo evolving } \\
\text { model }\end{array}$ & $190 / 19$ & $\begin{array}{l}\text { Evolving change in monoclonal } \\
\text { protein level (eMP) } \\
\text { Evolving change in hemoglobin (eHb) } \\
\geq 20 \% \text { BMPCs }\end{array}$ & $3 \mathrm{RF}$ & 2 -year: $90.5 \%$ & 29 \\
\hline
\end{tabular}

Abbreviations: BMPC, bone marrow plasma cell; NA, not available; PCs, plasma cells; RF, risk factors; SFLCR, serum free light chain ratio; SMM, smoldering multiple myeloma; TTP, time-to-progression.

have a beneficial effect in SMM patients was thalidomide. A Phase II trial showed partial responses in a third of the patients. ${ }^{55}$ However, thalidomide treatment was associated with significant toxicity. ${ }^{56,57}$ A later Phase III trial, ${ }^{58}$ conducted by the Mayo Clinic, compared thalidomide plus zoledronate versus zoledronate alone. The authors reported a response rate of $37 \%$ in the thalidomide arm (whereas no responses were seen in the zoledronate arm). Furthermore, the authors showed no significant difference in the TTP to MM (4.3 vs. 3.3 years) or in OS (74\% vs. $73 \%$ at 5 years). ${ }^{58}$ Based on these clinical trials, bisphosphonates are recommended only for SMM patients with osteoporosis. ${ }^{59}$

The benefits of early treatment were reported for the first time in a Phase III randomized trial (NCT00480363) performed by the Spanish Myeloma Group. ${ }^{60}$ One hundred and nineteen high-risk SMM patient fulfilling the Mayo and/or Spanish criteria were included in the study. The treatment arm included lenalidomide plus dexamethasone in the induction phase followed by lenalidomide alone in maintenance and was compared to the observation arm. The primary endpoint, TTP, was significantly longer in patients in the treatment than in the observation arm (not reached vs. 21 months; $P<0.001)$. Fifty-three out of $62(86 \%)$ patients in the observation group progressed to symptomatic MM compared with 22 out of $57(39 \%)$ patients in the treatment group. Furthermore, OS was longer in the treatment arm compared to the observation arm (3-year survival rate, 94\% vs. $80 \%, P<0.03)$. This study demonstrated for the first time that the OS of high-risk SMM patients can be improved by early treatment without significant side-effects. Despite the relevance of the results, some of its design problems have to be noted such as: 1) a high proportion of patients who progressed from SMM to MM within the first 6 months and might have been identified with routine MRI or PET-CT studies at baseline; 2) the median age of the control group 
was higher than the treatment group; 3) lack of crossover in the control arm at the time of biological progression; 4) design not fitted for regulatory purposes. Promising positive effects of early intervention have also been shown in an interventional Phase II study that tested the combination of carfilzomib, lenalidomide, and dexamethasone. Twelve highrisk SMM patients achieved at least near-complete response. Minimal residual disease (MRD) negativity was found in 11 out of 12 patients by flow cytometry and in 9 out of 12 by next-generation sequencing (NGS). This result highlights the methodologic differences between both platforms with the expected increased sensitivity of NGS. Furthermore, there was no significant association found between the degree of PET-CT response and clinical outcome or PFS. ${ }^{61}$

Current trials such as CESAR (NCT02415413) and ASCENT (NCT03289299) offer early treatment for high-risk SMM aiming in achieving sustained MRD-negative status and eradicating the disease. The debate around controlling the disease through continuous oral therapy versus the intensive therapy approaches, including high-dose therapy and transplantation with the possibility of "cure" is very controversial. The success of those approaches will probably depend on combinations of effective agents used and risk features of SMM. Finally, current trials are investigating the impact of early intervention with many novel agents or their combinations (Table 6).

\section{Management recommendation/follow-up}

The follow-up strategy for patients with SMM should be adapted to their risk of progression. As shown by the prospectively validated Mayo Clinic and Spanish models, the risk profile and TTP can differ significantly between the SMM subsets of patients. The risk assessment models differ, and each patient's risk of progression should probably be defined based on all the available data rather than with use of a restricted model. In general, SMM patients can be categorized into low, intermediate, and high risk of progression.

SMM patients with low risk of progression can be treated like patients with MGUS. The risk of progression in that group at 5 years is only $8 \%$. This group should be followed up annually. Patients at intermediate risk of progression display some high risk factors. The risk of progression in this cohort is estimated at $42 \%$ in 5 years. In the first year, patients should be followed every 3-4 months to exclude disease progression and then every 6 months. The high-risk patients require a closer follow-up, i.e., every 2-3 months.

Table 6 Overview of selected clinical trials for SMM patients

\begin{tabular}{|c|c|c|c|}
\hline $\begin{array}{l}\text { ClinicalTrials.gov } \\
\text { Identifier }\end{array}$ & Trial design & Interventional drug & Primary outcomes \\
\hline NCT02279394 & Phase II & Elotuzumab, lenalidomide, dexamethasone & TTP at 2 years \\
\hline NCT0290338I & Phase II & $\begin{array}{l}\text { Nivolumab, lenalidomide } \\
\text { dexamethasone }\end{array}$ & TTP at 2 years \\
\hline NCT029I677I & Phase II & Ixazomib, lenalidomide, dexamethasone & 2-years PFS rate \\
\hline NCT02603887 & Phase I & Pembrolizumab & ORR \\
\hline NCT024I54I3 & Phase II & Carfilzomib, lenalidomide, dexamethasone & Efficacy by Flow-CR at day 100 post ASCT \\
\hline NCT0I484275 & Phase II & Siltuximab & I-year PFS rate \\
\hline NCT02943473 & Phase II & Ibrutinib & TTP at I year \\
\hline NCT0I7I8899 & Phase $\mathrm{I} / \mathrm{lla}$ & PVX-4I0, a multi-peptide cancer vaccine & Safety and toxicity \\
\hline NCT02784483 & Phase I & Atezolizumab (anti-PD-LI) & $\begin{array}{l}\text { Prevalence of anti-SOX } 2 \text { reactive } T \text {-cells after } \\
\text { anti-PDLI therapy }\end{array}$ \\
\hline NCT03236428 & Phase I & Daratumumab & $\begin{array}{l}\text { Proportion of patients in deep response at } \\
\text { 2-year time }\end{array}$ \\
\hline NCT02697383 & Phase I & Ixazomib, dexamethasone & ORR at I year \\
\hline NCT02886065 & Phase lb & $\begin{array}{l}\text { PVX-4I0 (a multi-peptide cancer vaccine), } \\
\text { durvalumab, } \\
\text { +/- lenalidomide }\end{array}$ & Safety and toxicity \\
\hline NCT02960555 & Phase II & Isatuximab & ORR at 6 months \\
\hline NCT02492750 & Phase I/II & $\begin{array}{l}\text { Anakinra, lenalidomide } \\
\text { dexamethasone }\end{array}$ & $\begin{array}{l}\text { Safety and toxicity, } \\
\text { MTD, TTP at } 2 \text { years }\end{array}$ \\
\hline NCT02240537 & Phase I & $\begin{array}{l}\text { BBMPI03, an oncofetal antigen multi-peptide } \\
\text { immunotherapy }\end{array}$ & Safety and tolerability, DLT, MTD, and OBD \\
\hline
\end{tabular}

Note: Data from Muchtar et $\mathrm{al}^{62}$ and Mateos et $\mathrm{al}^{63}$

Abbreviations: ASCT, autologous stem cell transplantation; DLT, dose-limiting toxicity; MTD, maximum tolerated dose; OBD, optimal biologic dose; ORR, objective response rate; PFS, progression-free survival; SMM, smoldering multiple myeloma; TPP, time-to-progression. 
In our institution, we perform a comprehensive SMM workup (Table 2) including both PET-CT and WB-MRI. We also plan to extend it by adding immunprofiling and next generation flow cytometry in the near future. Currently, the risk of progression of individual patients is being discussed at the multidisciplinary meeting. Although we believe in the need of exploring early treatment, we do not treat high-risk SMM patients outside of the clinical trials. We are convinced that the translational studies including genetic and epigenetic factors, protein and phenotype analysis will help us define the subpopulation of patients that will benefit from the therapy, hopefully completely eradicating the progression to symptomatic disease.

\section{Future directions}

Until recently, treatment was reserved for symptomatic myeloma patients. This paradigm is now being challenged, as there is increased risk of progression into MM of certain SMM patient cohorts. In addition, there is now availability of novel, targeted drugs that may provide a more personalized treatment to SMM patients, combined with an acceptable side-effect profile.

Successful identification and validation of prognostic SMM to MM transition markers, such as CPCs, genetic and/ or proteomic profiles will inform and direct novel clinical trials that will be able to identify those SMM patients who will benefit from early intervention.

\section{Acknowledgment}

DB would like to acknowledge funding from the Irish Cancer Society.

\section{Disclosure}

POG has research support from Janssen and Celgene. The other authors report no conflicts of interest in this work.

\section{References}

1. Kyle RA, Greipp PR. Smoldering multiple myeloma. $N$ Engl J Med. 1980;302(24):1347-1349.

2. Rajkumar SV, Dimopoulos MA, Palumbo A, et al. International Myeloma Working Group updated criteria for the diagnosis of multiple myeloma. Lancet Oncol. 2014;15(12):e538-e548.

3. Ravindran A, Bartley AC, Holton SJ, et al. Prevalence, incidence and survival of smoldering multiple myeloma in the United States. Blood Cancer J. 2016;6(10): 4866.

4. Kristinsson SY, Holmberg E. Treatment for high-risk smoldering myeloma. N Engl J Med. 2013;369:1762-1765.

5. Rajkumar SV, Landgren O. Smoldering multiple myeloma. Blood. 2015;125(20):3069-3076.

6. Chang WJ, Kumar S, VanWier S, et al. Molecular dissection of hyperdiploid multiple myeloma by gene expression profiling. Cancer Res. 2007;67(7):2982-2989.
7. Rajkumar SV, Gupta V, Fonseca R, et al. Impact of primary molecular cytogenetic abnormalities and risk of progression in smoldering multiple myeloma. Leukemia. 2013;27(8):1738-1744.

8. Hanamura I, Stewart JP, Huang Y, et al. Frequent gain of chromosome band 1q21 in plasma-cell dyscrasias detected by fluorescence in situ hybridization: incidence increases from MGUS to relapsed myeloma and is related to prognosis and disease progression following tandem stem-cell transplantation. Blood. 2006;108(5):1724-1732.

9. Neben K, Jauch A, Hielscher T, et al. Progression in smoldering myeloma is independently determined by the chromosomal abnormalities del(17p), $\mathrm{t}(4 ; 14)$, gain 1q, hyperdiploidy, and tumor load. J Clin Oncol. 2013;31(34):4325-4332.

10. Dhodapkar MV, Sexton R, Waheed S, et al. Clinical, genomic, and imaging predictors of myeloma progression from asymptomatic monoclonal gammopathies (SWOG S0120). Blood. 2014;123(1):78-85.

11. Khan R, Dhodapkar M, Rosenthal A, et al. Four genes predict high risk of progression from smoldering to symptomatic multiple myeloma (SWOG S0120). Haematologica. 2015;100(9):1214-1221.

12. Chung TH, Mulligan G, Fonseca R, Chang WJ. A novel measure of chromosome instability can account for prognostic difference in multiple myeloma. PLoS One. 2013;8(6):e66361.

13. Shou Y, Martelli ML, Gabrea A, et al. Diverse karyotypic abnormalities of the c-myc locus associated with c-myc dysregulation and tumor progression in multiple myeloma. Proc Natl Acad Sci U SA. 2000;97(1): 228-233.

14. Chng WJ, Huang GF, Chung TH, et al. Clinical and biological implications of MYC activation: a common difference between MGUS and newly diagnosed multiple myeloma. Leukemia. 2011;25(6):1026-1035.

15. Chesi M, Bergsagel PL. Advances in the pathogenesis and diagnosis of multiple myeloma. Int J Lab Hematol. 2015;37(Suppl 1):108-114.

16. Manier S, Salem KZ, Park J, Landau DA, Getz G, Ghobrial IM. Genomic complexity of multiple myeloma and its clinical implications. Nat Rev Clin Oncol. 2016;13:100-113.

17. Walker BA, Wardell CP, Melchor L, et al. Intraclonal heterogeneity is a critical early event in the development of myeloma and precedes the development of clinical symptoms. Leukemia. 2014;28(2): 384-390.

18. Weinhold N, Heuck CJ, Rosenthal A, et al. Clinical value of molecular subtyping multiple myeloma using gene expression profiling. Leukemia. 2016; 30(2):423-430.

19. Mittermayr S, Lê GN, Clarke C, et al. Polyclonal Immunoglobulin G N -Glycosylation in the pathogenesis of plasma cell disorders. J Proteome Res. 2017;16(2):748-762.

20. Kyle RA, Remstein ED, Therneau TM, et al. Clinical course and prognosis of smoldering (asymptomatic) multiple myeloma. N Engl J Med. 2007;356(25):2582-2590.

21. Kyle RA, Larson DR, Therneau TM, et al. Clinical course of light-chain smoldering multiple myeloma (idiopathic Bence Jones proteinuria): a retrospective cohort study. Lancet Haematol. 2014;1(1):e28-e36

22. Rajkumar SV, Larson D, Kyle RA. Diagnosis of smoldering multiple myeloma. $N$ Engl J Med. 2011;365(5):474-475.

23. Kastritis E, Terpos E, Moulopoulos L, et al. Extensive bone marrow infiltration and abnormal free light chain ratio identifies patients with asymptomatic myeloma at high risk for progression to symptomatic disease. Leukemia. 2013;27(4):947-953.

24. Waxman AJ, Mick R, Garfall AL, et al. Classifying ultra-high risk smoldering myeloma. Leukemia. 2015;29(3):751-753.

25. Larsen JT, Kumar SK, Dispenzieri A, Kyle RA, Katzmann JA, Rajkumar $\mathrm{S}$ V. Serum free light chain ratio as a biomarker for high-risk smoldering multiple myeloma. Leukemia. 2013;27(4):941-946.

26. Dispenzieri A, Kyle RA, Katzmann JA, et al. Immunoglobulin free light chain ratio is an independent risk factor for progression of smoldering multiple myeloma. Blood. 2008;111(2):785-789.

27. Sørrig R, Klausen TW, Salomo M, et al. Smoldering multiple myeloma risk factors for progression: a Danish population-based cohort study. Eur J Haematol. 2016;97(3):303-309. 
28. Rosiñol L, Bladé J, Esteve J, et al. Smoldering multiple myeloma: natural history and recognition of an evolving type. Br J Haematol. 2003;123(4):631-636.

29. Ravi P, Kumar S, Larsen JT, et al. Evolving changes in disease biomarkers and risk of early progression in smoldering multiple myeloma. Blood Cancer J. 2016;6(7):e454.

30. Fernandez de Larrea C, Isola I, Cibeira MT, et al. Smoldering multiple myeloma: impact of the evolving pattern on early progression. $\mathrm{ASH}$ 2014. 2014;124(21):3363a.

31. González-Calle V, Dávila J, Escalante F, et al. Bence Jones proteinuria in smoldering multiple myeloma as a predictor marker of progression to symptomatic multiple myeloma. Leukemia. 2016;30(10):2026-2031.

32. Pérez-Persona E, Vidriales M-B, Mateo G, et al. New criteria to identify risk of progression in monoclonal gammopathy of uncertain significance and smoldering multiple myeloma based on multiparameter flow cytometry analysis of bone marrow plasma cells. Blood. 2007;110(7):2586 -2592.

33. Billadeau D, Van Ness B, Kimlinger T, et al. Clonal circulating cells are common in plasma cell proliferative disorders: a comparison of monoclonal gammopathy of undetermined significance, smoldering multiple myeloma, and active myeloma. Blood. 1996;88(1):289-296.

34. Nowakowski GS, Witzig TE, Dingli D, et al. Circulating plasma cells detected by flow cytometry as a predictor of survival in 302 patients with newly diagnosed multiple myeloma. Blood. 2005;106(7):2276-2279.

35. Bianchi G, Kyle RA, Larson DR, et al. High levels of peripheral blood circulating plasma cells as a specific risk factor for progression of smoldering multiple myeloma. Leukemia. 2013;27(3):680-685.

36. Gonsalves WI, Rajkumar SV, Dispenzieri A, et al. Quantification of circulating clonal plasma cells via multiparametric flow cytometry identifies patients with smoldering multiple myeloma at high risk of progression. Leukemia. 2016;31(1):130-135.

37. Hillengass J, Fechtner K, Weber MA, et al. Prognostic significance of focal lesions in whole-body magnetic resonance imaging in patients with asymptomatic multiple myeloma. J Clin Oncol. 2010;28(9):1606-1610.

38. Merz M, Hielscher T, Wagner B, et al. Predictive value of longitudinal whole-body magnetic resonance imaging in patients with smoldering multiple myeloma. Leukemia. 2014;28(9):1902-1908

39. Kastritis E, Moulopoulos LA, Terpos E, Koutoulidis V, Dimopoulos MA. The prognostic importance of the presence of more than one focal lesion in spine MRI of patients with asymptomatic (smoldering) multiple myeloma. Leukemia. 2014;28(12):2402-2403.

40. Cavo M, Terpos E, Nanni C, et al. Role of 18 F-FDG PET/CT in the diagnosis and management of multiple myeloma and other plasma cell disorders: a consensus statement by the International Myeloma Working Group. Lancet Oncol. 2017;18(4):e206-e217.

41. Zamagni E, Nanni C, Gay F, et al. 18F-FDG PET/CT focal, but not osteolytic, lesions predict the progression of smoldering myeloma to active disease. Leukemia. 2016;30(2):417-422.

42. Siontis B, Kumar S, Dispenzieri A, et al. Positron emission tomographycomputed tomography in the diagnostic evaluation of smoldering multiple myeloma: identification of patients needing therapy. Blood Cancer J. 2015;5(10):e364.

43. Pérez-Persona E, Mateo G, García-Sanz R, et al. Risk of progression in smoldering myeloma and monoclonal gammopathies of unknown significance: comparative analysis of the evolution of monoclonal component and multiparameter flow cytometry of bone marrow plasma cells. Br J Haematol. 2010;148(1):110-114.

44. Zamagni E, Patriarca F, Nanni C, et al. Prognostic relevance of 18-F FDG PET/CT in newly diagnosed multiple myeloma patients treated with up-front autologous transplantation. Blood. 2011;118(23): 5989-5995.
45. Cherry BM, Korde N, Kwok M, et al. Modeling progression risk for smoldering multiple myeloma: results from a prospective clinical study. Leuk Lymphoma. 2013;54(10):2215-2218.

46. Waxman AJ, Mick R, Garfall AL, et al. Modeling the risk of progression in smoldering multiple myeloma. JCO. 2014;32(15_Suppl):8607a.

47. Hajek R, Sandecka V, Seckinger A, et al. Prediction of progression of smoldering into therapy requiring multiple myeloma by easily accessible clinical factors [in 527 patients]. ASH 2014. 2014;124(21):2071a.

48. Fernández de Larrea C, Isola I, Cibeira MT, et al. Smoldering Multiple Myeloma: impact of the evolving pattern on early progression. Blood. 2014;124(21): 3363.

49. Muta T, Iida S, Matsue K, et al. Predictive significance of serum Beta 2-Microglobulin levels and M-protein velocity for symptomatic progression of smoldering multiple myeloma. Blood. 2014;124(21): 3379.

50. Hjorth M, Hellquist L, Holmberg E, Magnusson B, Rödjer S, Westin J. Initial versus deferred melphalan-prednisone therapy for asymptomatic multiple myeloma stage I: a randomized study. Eur J Haematol. 1993;50(2):95-102.

51. Riccardi A, Mora O, Tinelli C, et al. Long-term survival of stage I multiple myeloma given chemotherapy just after diagnosis or at progression of the disease: a multicentre randomized study. Cooperative Group of Study and Treatment of Multiple Myeloma. Br J Cancer. 2000;82(7):1254-1260.

52. Martín A, García-Sanz R, Hernández J, et al. Pamidronate induces bone formation in patients with smoldering or indolent myeloma, with no significant anti-tumor effect. Br J Haematol. 2002;118(1):239-242.

53. Musto P, Petrucci MT, Bringhen S, et al. A multicenter, randomized clinical trial comparing zoledronic acid versus observation in patients with asymptomatic myeloma. Cancer. 2008;113(7):1588-1595.

54. D’Arena G, Gobbi PG, Broglia C, et al. Pamidronate versus observation in asymptomatic myeloma: final results with long-term follow-up of a randomized study. Leuk Lymphoma. 2011;52(5):771-775.

55. Rajkumar SV, Gertz MA, Lacy MQ, et al. Thalidomide as initial therapy for early-stage myeloma. Leukemia. 2003;17(4):775-779.

56. Detweiler-Short K, Hayman S, Gertz MA, et al. Long-term results of single-agent thalidomide as initial therapy for asymptomatic (smoldering or indolent) myeloma. Am J Hematol. 2010;85(10):737-740.

57. Barlogie B, Van Rhee F, Shaughnessy JD, et al. Seven-year median time to progression with thalidomide for smoldering myeloma: partial response identifies subset requiring earlier salvage therapy for symptomatic disease. Blood. 2008;112(8):3122-3125.

58. Witzig TE, Laumann KM, Lacy MQ, et al. A phase III randomized trial of thalidomide plus zoledronic acid versus zoledronic acid alone in patients with asymptomatic multiple myeloma. Leukemia. 2012;27(1):1-29.

59. Terpos E, Morgan G, Dimopoulos MA, et al. International myeloma working group recommendations for the treatment of multiple myelomarelated bone disease. J Clin Oncol. 2013;31(18):2347-2357.

60. Mateos M-V, Hernández M-T, Giraldo P, et al. Lenalidomide plus Dexamethasone for high-risk smoldering multiple myeloma. $N$ Engl J Med. 2013;369(5):438-447.

61. Korde N, Roschewski M, Zingone A, et al. Treatment with carfilzomiblenalidomide-dexamethasone with lenalidomide extension in patients with smoldering or newly diagnosed multiple myeloma. JAMA Oncol. 2015;1(6):746-754.

62. Muchtar E, Kumar SK, Magen H, Gertz MA. Diagnosis and management of smoldering multiple myeloma: the razor's edge between clonality and cancer. Leuk Lymphoma. 2017;8194:1-12.

63. Mateos M-V, González-Calle V. Smoldering Multiple Myeloma: Who and When to Treat. Clin Lymphoma Myeloma Leuk. 2017:1-7. 
Blood and Lymphatic Cancer: Targets and Therapy is an international, peer-reviewed, open access journal focusing on blood and lymphatic cancer research, identification of therapeutic targets and the optimal use of preventative and integrated treatment interventions to achieve improved outcomes, enhanced survival and quality of life for the cancer patient. The manuscript management system is completely online and includes a very quick and fair peer-review system. Visit $\mathrm{http}: / /$ www.dovepress.com/testimonials.php to read real quotes from published authors.

Submit your manuscript here: https://www.dovepress.com/blood-and-lymphatic-cancer-targets-and-therapy-journal 